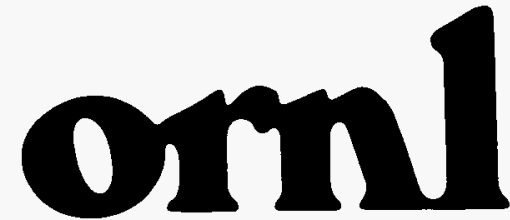

OAK RIDGE NATIONAL LABORATORY
MARTIN MARIETRA

MARTIN MARIETTA ENERGY SYSTEMS, INC. FOR THE UNITED STATES DEPARTMENT OF ENERGY

ORNL/TM-13007

Technical Support for the Ukrainian State Committee for

Nuclear Radiation Safety on

Specific Waste Issues

C.A. Little

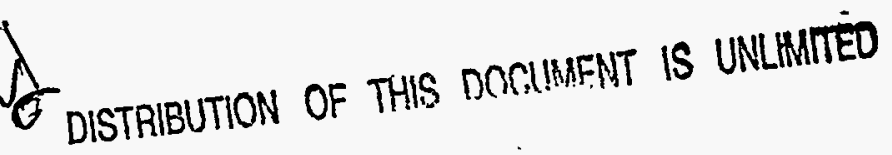


This report has been reproduced direclly from the best available copy.

Available to DOE and DOE contractors from the Office of Scientific and Technical Information, P.O. Box 62, Oak Ridge, TN 37831; prices available from (615) 576-8401, FTS 626-8401.

Available to the public from the National Technical Information Service, U.S. Department of Cormmerce, 5285 Port Royal Rd., Springfield, VA 22161.

This report was prepared as an account of work sponsored by an agency of the United States Government. Neither the United States Government nor any agency thereof, nor any of their employees, makes any warranty, express or implied, or assumes any legal liability or responsibility for the accuracy, completeness, or usefulness of any information, apparatus, product, or process disclosed, or represents that its use would not infringe privately owned rights. Reference herein to any specific commercial product, process, or service by trade name, trademark, manufacturer, or otherwise, does not necessarily constitute or imply its endorsement, recommendation, or favoring by the United States Government or any agency thereof. The views and opinions of authors expressed herein do not necessarily state or reflect those of the United States Government or any agency thereof. 


\title{
Technical Support for the Ukrainian State Committee for Nuclear Radiation Safety on Specific Waste Issues
}

\author{
C.A. Little
}

Published:

Prepared by the OAK RUGE NATIONAL LABORATORY

Grand Junction, Colorado 81503 managed by MARTIN MARIETTA ENERGY SYSTEMS, INC.

for the

U. S. DEPARTMENT OF ENERGY under contract DE-AC05-84OR21400 


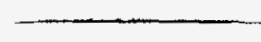

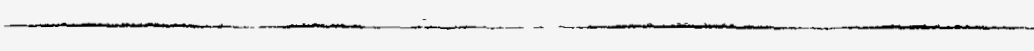

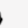

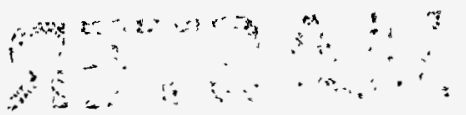




\section{DISCLAIMER}

Portions of this document may be illegible in electronic image products. Images are produced from the best available original document. 


\section{CONTENTS}

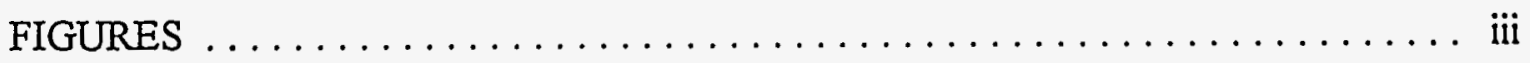

ACRONYMS, ABBREVIATIONS, AND INITIALISMS $\ldots \ldots \ldots \ldots \ldots \ldots$ iv

1. INTRODUCTION $\ldots \ldots \ldots \ldots \ldots \ldots \ldots \ldots \ldots \ldots \ldots \ldots \ldots \ldots \ldots \ldots$

2. THE ZHELTYE VODY SITE $\ldots \ldots \ldots \ldots \ldots \ldots \ldots \ldots \ldots \ldots \ldots \ldots \ldots \ldots$

3. MILLING OPERATIONS $\ldots \ldots \ldots \ldots \ldots \ldots \ldots \ldots \ldots \ldots \ldots \ldots$

4. LICENSING ISSUES $\ldots \ldots \ldots \ldots \ldots \ldots \ldots \ldots \ldots \ldots \ldots \ldots \ldots \ldots \ldots \ldots$

4.1 TAILINGS LOCATION $\ldots \ldots \ldots \ldots \ldots \ldots \ldots \ldots \ldots \ldots \ldots \ldots$

4.2 DISRUPTION AND DISPERSION BY NATURAL FORCES $\ldots \ldots \ldots \ldots 7$

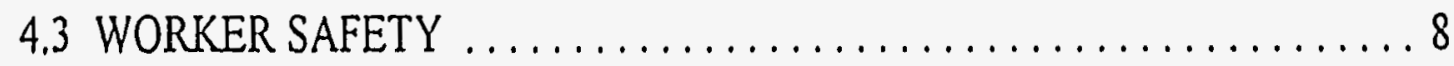

4.4 OPERATIONAL PROCEDURES AND QUALITY ASSURANCE ...... 8

4.5 DAM SAFETY $\ldots \ldots \ldots \ldots \ldots \ldots \ldots \ldots \ldots \ldots \ldots \ldots \ldots \ldots \ldots \ldots \ldots \ldots \ldots$

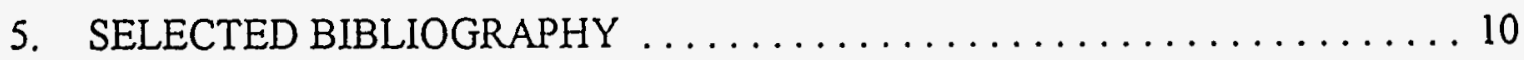

APPENDIX A ZHELTYE VODY TRIP ITINERARY AND NOTES

\section{FIGURES}

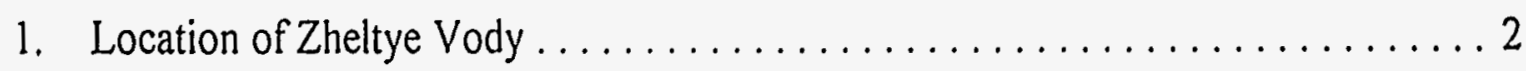

$\theta_{6}^{i i i}$ DISTRIBUTION OF THIS DCCUMENT IS UNEMITED 


\section{ACRONYMS, ABBREVLATIONS, AND INITIALISMS}

$\begin{array}{ll}\text { atm } & \begin{array}{l}\text { atmosphere } \\ \text { becquerel }\end{array} \\ \mathrm{cm} & \text { centimeter } \\ \mathrm{ha} & \text { hectare } \\ \mathrm{km} & \text { kilometers } \\ \mathrm{m} & \text { meter } \\ \mathrm{NRC} & \text { U.S. Nuclear Regulatory Commission } \\ \text { OSHA } & \text { Occupational Safety and Health Administration } \\ \mathrm{pCi} / \mathrm{L} & \text { picocuries per liter } \\ \mathrm{Ra} & \text { radium } \\ \text { SCNRS } & \text { State Committee for Nuclear and Radiation Safety } \\ \text { SPA } & \text { Scientific Production Association }\end{array}$




\section{INTRODUCTION}

The government of Ukraine, a now-independent former member of the Soviet Union, has asked the United States to assist its State Committee for Nuclear and Radiation Safety (SCNRS) in improving its regulatory control in technical fields for which it has responsibility. The U.S. Nuclear Regulatory Commission (NRC) is providing this assistance in several areas, including management of radioactive waste and spent fuel. Radioactive wastes resulting from nuclear power plant operation, maintenance, and decommissioning must be stored and ultimately disposed of appropriately. In addition, radioactive residue from radioisotopes used in various industrial and medical applications must be managed.

The objective of this program is to provide the Ukrainian SCNRS with the information it needs to establish regulatory control over uranium mining and milling activities in the Zheltye Vody (Yellow Waters) area and radioactive waste disposal in the Pripyat (Chernobyl) area among others. The author of this report, head of the Environmental Technology Section, Health Sciences Research Division of Oak Ridge National Laboratory, accompanied NRC staff to Ukraine to meet with SCNRS staff and visit sites in question. The report highlights problems at the sites visited and recommends license conditions that SCNRS can require to enhance safety of handling mining and milling wastes. The author's responsibility was specifically for the visit to Zheltye Vody and the mining and milling waste sites associated with that facility. An itinerary for the Zheltye Vody portion of the trip is included as Appendix A.

\section{THE ZHELTYE VODY SITE}

Zheltye Vody is a town of 67,000 inhabitants located approximately $430 \mathrm{~km}$ southsoutheast of Kiev in the Dnepropetrovsk region of Ukraine (Fig. 1). Until early 1993, 


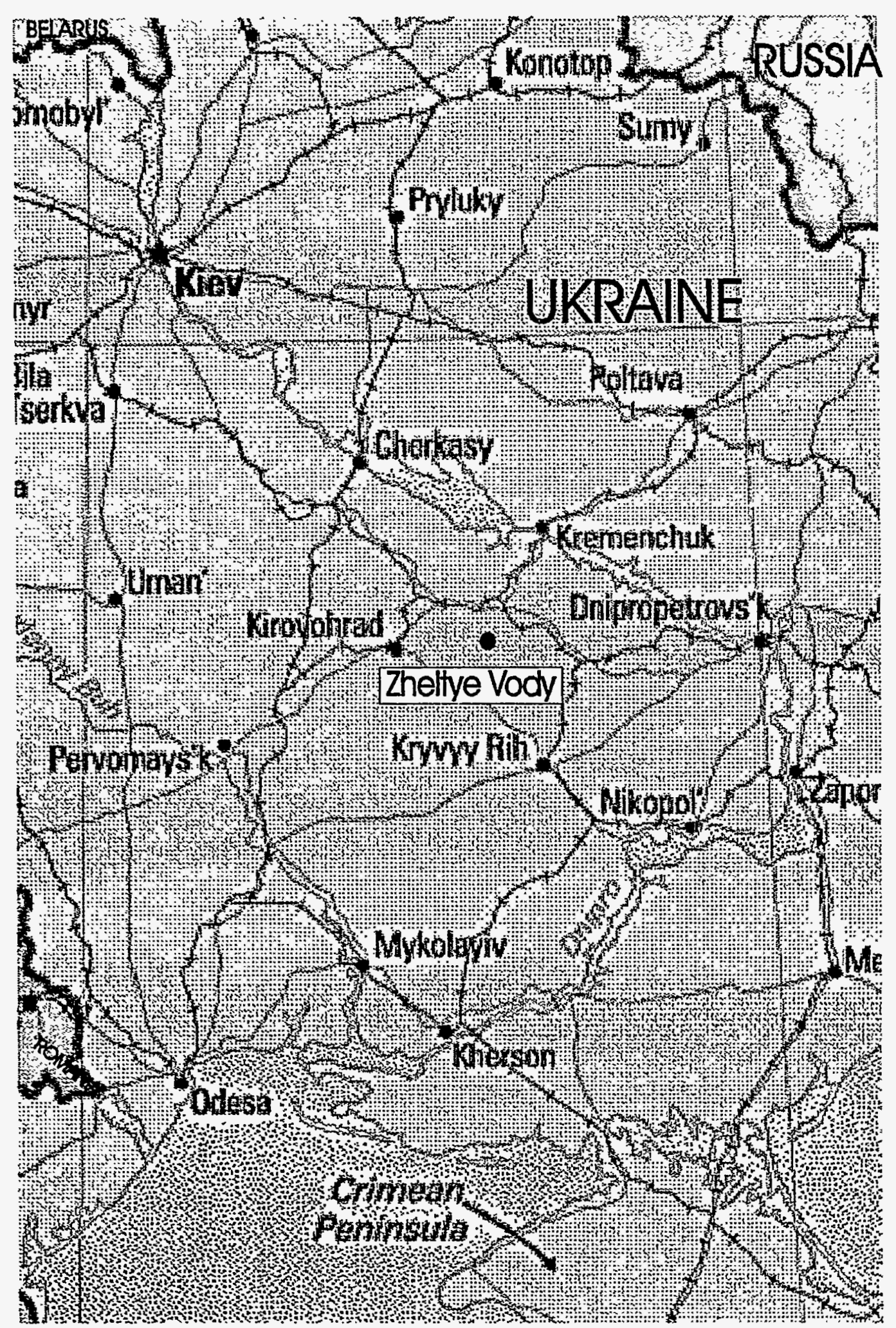

Fig. 1. Location of Zheltye Vody. 
milling operations in the town were under nominal control of the military. The mining and milling operations are part of what is known in English as the Scientific Production Association (SPA).

A brief verbal history of the Zheltye Vody region was provided to the American and Ukrainian visitors by Mr. Bezrodniy, who oversees the mill operation known as the Eastern Ore-Dressing Factory. Iron ore has been mined in this region since 1892 by both underground and open-pit mines. Radium was discovered here in the 1930s. In the 1950s, the Soviet parliament ordered the Ministry of Medium Machinery to start uranium exploration. At that time, the city of Zheltye Vody did not exist, and there was only a small village in the vicinity. Mining and milling for uranium started in the late 1950s, with the "enrichment plant" being built in 1958. The term "enrichment plant" is a misnomer because there are no uranium enrichment facilities located in Ukraine. The mill produces $\mathrm{UO}_{2}$, which is "pure enough that there is no further processing needed" according to Mr. Bezrodniy. There were three mines in Zheltye Vody proper in the late 1950s, but they are now depleted. Ore now comes from the Kirovgrad region, approximately $100 \mathrm{~km}$ from Zheltye Vody. Nearly 5,000 people work for SPA, but less than 100 are associated directly with the mill. SPA oversees a power plant, water purification plant, collective farm, bakery, sulfuric acid factory, and other entities required to make the town more or less self-sufficient. There are two small research institutes in Zheltye Vody, one that performs chemical and physical analytical work and another that does a variety of work for SPA. SPA has established several joint ventures with outside entities including (1) Design Logistics of U.S. in order to mine granite using diamond-tipped saws; (2) a Canadian firm that will mine scandium ore; and (3) the Russians, who are building a small oil refinery.

According to Mr. Bezrodniy, the SPA Eastern Ore-Dressing Factory at one time produced one third to one half of the world's uranium. The production rate is now considerably less and varies monthly, depending on "the market". The facility is now in a difficult period because of the poor economy. SPA is continuing geological research in the region in order to increase known reserves of gold, manganese, and scandium ore. 


\section{MULING OPERATIONS}

From discussions with the staff and viewing a video of the facility, the Kirovgrad uranium mines appear to be relatively modern. Ore, which was said to be granitic, is raised to the surface and placed onto railroad cars for transport to Zheltye Vody. Upon arrival, the cars are dumped by an automated system that upends the cars. A rubber conveyor belt transfers the ore into the mill itself. Milling operations begin with a series of large ball mills, approximately $3 \mathrm{~m}$ in diameter, in which ore is crushed in the presence of water. The slurry is treated with sulfuric acid and organic chemicals to leach uranium from the ore.

The uranium oxide that results from the milling process is a fine dark-gray powder. Since Ukraine does not have gaseous diffusion or fuel fabrication facilities, uranium oxide is shipped to Russia for completion of the fuel cycle. The completed fuel is returned to Ukraine for use in reactors.

The major by-product of the milling process is a water-borne slurry of uranium mill tailings. There are five tailings ponds, of which only two were active during the visit. At the unused ponds where dust problems exist, SPA sprays a $0.1 \%$ solution of acrylic amide (chemical name may be wrong in translation) on the ponds to limit wind erosion of the banks.

The active disposal ponds are $13 \mathrm{~km}$ south of the mill. A 40-cm-diameter pipe carries the slurry through the town to the disposal ponds where the tailings are discharged. Water usage at the plant is reportedly a closed loop, with water from the largest pond being pumped back to the mill via a return pipe system. The largest pond is on the order of 100 ha in area, with an original depth of up to $85 \mathrm{~m}$. Tailings disposal has decreased depth of the water to only $25 \mathrm{~m}$, the bottom $60 \mathrm{~m}$ being settled tailings. 
The tailings pond areas, while posted, are not particularly secure. There was no gate to physically prevent access by automobile, and fencing around the lake was minimal. Efforts to fence the lake have failed because according to Mr. Zhukov of the SPA staff, "people steal the fence". The acidity of the lake is low enough that emergent vegetation populates the shoreline. Algae, crawfish and fish are also present. Fishing by the general public occurs even though access is not allowed. SPA staff have harvested some of the fish and found $\mathrm{Ra}$ in the bones, which is to be expected, but not in the flesh, which may be inconsistent depending on the type of assay conducted. There was no information available regarding contamination levels or the lower limit of detection of the radiological assay equipment used.

There are a series of monitoring wells ringing these lakes, but they were not evident. Although SPA staff offered no data, they stated that sampling of groundwater has yielded no elevated concentrations of radionuclides in wells downgradient of the lake. Sulfates have been seen in elevated concentrations, however.

At current usage rates, the large tailings pond has only seven years of capacity remaining. The preferred method of increasing capacity being considered by the staff of the mill is to raise the dam on the lake by as much as $17 \mathrm{~m}$. This alternative would allow several more decades of use of this lake.

The slurry method of tailings disposal avoids some problems that drier American piles may have. First, there is likely to be less radon emission from these ponds because the tailings are always wet. Wet tailings also prevent or minimize construction or casual uses by members of the public. Although there was some use of ore in roads and sidewalks and by homeowners for construction purposes, Mr. Zhukov indicated that there was never any use of tailings by the public in Zheltye Vody. The local Design and Research Institute of Production Engineering developed procedures to remove the material from the city. It was not clear whether that work was completed. 


\section{LICENSING ISSUES}

Observations made during the visit indicated obvious issues that would arise if an NRC-type license were to be written by SCNRS. Although there is no assurance that SCNRS staff will be supported by empowering legislation that mimics U.S. law or that their stipulations will imitate NRC regulations, it may be instructive to point out some licensing issues that pertain to the Zheltye Vody operation.

\subsection{TAMINGS LOCATION}

Issue: $\quad$ Tailings disposal locations should be remote so that population exposures would be reduced to the maximum extent reasonably achievable.

Resolution: Because of the relatively dense nature of the population in the Zheltye Vody region, it is not possible to dispose of the tailings in a remote location. Therefore, the licensee should take whatever steps are possible to reduce human contact with water, spilled tailings, contaminated vegetation, and fish.

Possible solutions within the realm of the foreseeable budget include:

(1) more rigorous exclusionary posting of the tailings lake region and its access roads, (2) prosecution of offenders, and (3) removal of fish from the lake to make it less attractive. 


\subsection{DISRUPTION AND DISPERSION BY NATURAL FORCES}

Issue: $\quad$ The wet nature of the tailings transport and disposal makes it likely that contaminants are being leached into the groundwater, affecting off-site wells and waterways.

Resolution: The licensee should ensure that existing monitoring wells adequately represent groundwater flow and groundwater contamination. A piezometric map of the region drawn from existing wells or a groundwater flow model should be developed or referenced by the licensee so that the regulator can determine whether or not monitoring wells are correctly placed.

Well installation and construction methods should be described and evaluated by a qualified hydrologist not associated with the licensee.

Periodic (quarterly or annual) results of groundwater monitoring data should be published or provided to the regulator and to the public. Analyses should include both radioactive $\left({ }^{226} \mathrm{Ra}\right.$, $\left.{ }^{\text {nat }} \mathrm{U},{ }^{230} \mathrm{Th}\right)$ and nonradioactive (sulfate, nitrate, organic) constituents.

New impoundments should be designed to minimize leaching. Impermeable, synthetic liners are preferred, but may be difficult to acquire in Ukraine. In the absence of synthetic liners, a natural clay liner should be used.

Issue:. Windblown tailings and radon emanation from older, unused disposal ponds may pose a risk to both workers and members of the public. 
Resolution: The licensee should continue to utilize dust entrainment sprays to prevent dust from spreading. Air sampling or experimental data should be provided to verify that the methods used are adequate to control exposures.

The licensee should propose a long-term plan for abandonment of the unused ponds, using a cover that is adequate to prevent erosion and limits radon exposure of the general public to the dry tailings materials. The radon emanation rate from the impoundment area should be reduced to about twice the emanation rate in the surrounding environs. The cover should reduce direct gamma radiation from the impoundment area to essentially background.

\subsection{WORKER SAFETY}

Issue: There was no evidence of radiological monitoring or worker protection.

Resolution: The licensee should provide evidence that applicable Ukrainian standards for protection of radiological workers from radiation are not being violated. The licensee should develop a plan to demonstrate that adequate steps are being taken to protect workers from unnecessary exposures.

\subsection{OPERATIONAL PROCEDURES AND QUALITY ASSURANCE}

Issue: There was no evidence of either operational procedures or a quality assurance program. 
Resolution: The licensee should develop and maintain written procedures that describe operations involving radioactive materials. Procedures should incorporate operating instructions and appropriate safety precautions for the work being conducted, including but not limited to: radiation safety programs, environmental monitoring programs, analytical processes, and instrument calibration. Written procedures and subsequent changes should be reviewed and approved in writing by appropriate licensee staff. All procedures should be reviewed at least annually to ensure continued applicability.

An independent quality assurance audit should be performed at least annually to ensure that all applicable procedures are being conducted as written. All equipment used for analysis of radiologic or non-radiologic materials should be calibrated and documented at least annually.

\subsection{DAM SAFETY}

Issue: $\quad$ Failure of the existing dam would spread tailings material over a wide region, which might result in acute damage to downstream communities.

Resolution: The existing dam on the large tailings pond should be inspected by a qualified engineer. The licensee should provide a written dam inspection report to the regulator. Any plans to expand the tailings pond by raising the dam should be forwarded to the regulator for approval prior to initiating construction. 


\section{SELECTED BIBLIOGRAPHY}

UDEQ. 1989. Radioactive Material License for Envirocare of Utah, Inc. License No. DRC-03. Division of Radiation Control, Utah Department of Environmental Quality, Salt Lake City, Utah.

U.S. NRC. 1988. Standard Format and Content of a License Application for a LowLevel Radioactive Waste Disposal Facility. NUREG-1199. Safety Analysis Report, Rev. 1. U.S. Nuclear Regulatory Commission.

U.S. NRC. 1988. Standard Review Plan for the Review of a License Application for a Low-Level Radioactive Wasle Disposal Facility. NUREG-1200. Safety Analysis Report, Rev. 1. U.S. Nuclear Regulatory Commission.

U.S. NRC. 1987. Environmental Standard Review Plan for the Review of a License Application for a Low-Level Radioactive Waste Disposal Facility. NUREG1300. U. S. Nuclear Regulatory Commission.

U.S. NRC. 1981. Draft Environmental Impact State on 10 CFR Part 61 "Licensing Requirements for Land Disposal of Radioactive Waste". NUREG-0782. Main Report, Vol. 2, Part 2. U.S. Nuclear Regulatory Commission. 


\section{APPENDIX A}

ZHELTYE YODY TRIP ITINERARY AND NOTES 


\section{APPENDIX A \\ ZHELTYE VODY TRIP ITINERARY AND NOTES}

This side trip focused on issues associated with the potential licensing of the SPA uranium milling operation in and around the town of Zheltye Vody in the Dnepropetrovsk region of Ukraine. The delegation from Kiev included Mrs. Ludmilla Bogdan and Mr. Nicholai Bereshnoi of SCNRS, Dr. Michael Tokar of NRC, translator Mr. Boris Landa, and the author.

October 3, 1994

We were driven by car from Kiev to Zheltye Vody. The trip took approximately seven hours through largely agricultural land. A portion of the trip was near the lake created by damming the Dnieper River. We were housed in a guest hotel largely reserved for foreign business people or visitors to the facility.

October 4, 1994

\section{9:00 Director of the hydrometallurgical plant}

Our first meeting of the day was with the Director of the Hydrometallurgical Plant, Mr. Stanislav A. Bezrodniy, in his office. He was accompanied by Mr. Zhukov, his deputy and public relations representative.

Mrs. Bogdan introduced the need for a license, which SCNRS hopes to develop but without which everyone works at this time. To develop these licenses, an assistance program has been established whereby the U.S. provides consultation with U.S. technical experts, training for Russian specialists in the U.S., or direct technical assistance to Ukraine. Mr. Bezrodniy asked what kind of experts had been sent this time. In response, 
Dr. Tokar and I described our backgrounds. Mr. Bezrodniy then spent considerable time describing the organization, history, and operation of the SPA Eastern Ore-Dressing Factory. This information is located in Sect. 2 of this report.

\section{0:15 Hydrometallurgical plant manager}

We were transported to the mill itself and introduced to Mr. Petr G. Perkov, Director of the Vostgok Hydrometallurgical plant. He briefed us on the history and operation of the plant. As mentioned by Mr. Bezrodniy, the plant was built in 1958 and began producing $\mathrm{UO}_{2}$ in 1959. The ore currently comes from Kirovgrad via rail. Rail cars are dumped upside down, and the ore is conveyed via belt to two crusher units, one for larger sizes, one for smaller. Water is added to form a slurry, which is then piped to an autoclave where sulfuric acid is added and a pressure of $15 \mathrm{~atm}$ applied. The slurry enters an adsorption phase and is then desorbed by use of organic chemicals similar to kerosene. Whereas American plants use filters, there are none at the Vostgok plant. The resulting dark $\mathrm{UO}_{2}$ crystals look more like powder than crystals.

Other products from the SPA plant include an Al alloy with $2 \%$ scandium, which increases strength nearly $100 \%$ over unalloyed metal. Pure scandium metal is also produced, as well as $\mathrm{ScF}$.

We were shown the entire plant, which was impressively large by American standards. The crusher units were on the order of 2 to $3 \mathrm{~m}$ in diameter and ran at a high rate of speed. The plant would not be acceptable to Occupational Safety and Health Administration (OSHA) because of many mechanical and electrical hazards (open, accessible high-speed equipment and many extension cords). Only 35 people work in the mill at any single time; most operations are remotely controlled from several control rooms. A computer center monitors all flow rates, and many of them can be changed from that center. The main plant building is on the order of $300 \mathrm{~m} \times 50 \mathrm{~m} \times 40 \mathrm{~m}$. 


\section{2:30 Lunch}

\section{1:30 Visit to the tailings disposal areas}

As with all mills, the major by-product of the hydrometallurgical plant is tailings. However, in this case, the tailings are not left on the site of the mill itself. As slurry they are piped to disposal ponds $13 \mathrm{~km}$ from the plant. The water usage at the plant is reportedly a closed loop, with water from the largest pond being pumped back to the mill via a return pipe system. The largest pond must be on the order of 100 ha in area and is up to $25 \mathrm{~m}$ deep in places. We saw a total of five ponds, only two of which are currently active. While this method of tailings disposal avoids some problems that American piles may have, it has some other problems absent in the American system. First, there is likely to be less radon emission from these ponds because the tailings are always wet. However, this wetness likely leads to leaching and communication with the groundwater, which would not be allowed by American regulators. Monitoring wells reportedly surround these piles, but we were not shown any. Second, as the ponds have matured, they have acquired natural grasses, invertebrates, and fish. The fish are large enough to harvest and have become an attraction for the surrounding population. Efforts to fence the ponds to prevent intrusion have failed because the populace stole the barbed wire. SPA has reportedly harvested some of the fish and found $\mathrm{Ra}$ in the bones, which is to be expected, but not in the flesh.

The wet tailings have also prevented another American problem, that of construction or casual uses by members of the public. Although there was some use of ore by homeowners for construction purposes, there has never been any use of tailings. According to Mr. Perkov, experience in Russia provided that lesson before this plant was opened.

In situations where dust problems exist, they use a $0.1 \%$ solution of acrylic amide (probably wrong in translation because the translator was unfamiliar with the chemical terms). The solution is sprayed on the piles via helicopter. 
I saw no health physics monitoring of the workers. I have no way to verify the sampling of the wells or the results because we weren't shown any. I doubt that they have any radon sampling of the air around either the mill or the mill ponds.

\section{October 5, 1994}

\section{9:00 Ukrainian Design and Research Institute of Production Engineering}

We met with Mr Masliakov, Head Engineer of the Institute, and with approximately 12 of his staff. Mr. Masliakov gave an overview of the Institute. Major activities of the institute include design of equipment for mining uranium and "enrichment" to the $\mathrm{UO}_{2}$ form, design of housing, environmental protection, and security and safety of radioactive materials.

Major laboratories within the Institute include:

- the Laboratory for Industrial Technology for Mining, which develops technology for underground mining, develops procedures to respond to seismic activity, and provides radiation "security" for people working underground;

- the Laboratory for Environmental Protection, which monitors environmental pollution, provides the scientific basis for reclamation of land, and provides safety for radiation handling;

- the Mechanics Laboratory, which develops "vibration" equipment for transport and unloading of uranium ore in the mine and mill;

- the Special Design Technology Laboratory, which coordinates the disposal of radioactive waste; 
Four of the institute staff made presentations about their projects:

- Boris Karpenko, a chief engineer, discussed work to stabilize the mill tailings beaches. He said that they are interested in reducing dust emissions and have, therefore, created a compound sprayed on the beach to coagulate and hold the sand in place. They have reportedly tested the material, "which is a certain plastic," and find that it works well. They have also tested "certain by-products of their milling process" left over from the sulfuric acid baths and also a residue from burning of coal (ash). They found that all of these worked, but no data were presented.

- Valentin Zelnichenko, Assistant Head Engineer working with radioactive wastes, discussed projects associated with usage (or disposal) of mill tailings. They are looking at the possibility of replacing the tailings in the mine by hardening them. Presumably they will add some concrete or other hardening agent to the tailings slurry then pump it into the abandoned mine. When the tailings harden, they are hoping that radon emissions will be reduced from what they might be without the concreting action. When designing new mines, they are now taking into account plans to dispose of tailings in this manner. No data were presented.

- Yuri Soroka, Chief of the Scientific Laboratory, discussed reclamation studies having to do with the tailings ponds themselves. The ecological group, founded in 1976, developed some test pits in 1977 with different styles and compositions of soil/rock/clay caps for covering tailings. They took radon measurements and grew agricultural products to see what tailings materials were taken up into the plants. I asked him which compositions worked best, but my question went unanswered. No data were presented. 
- Alexander Molchanov, Scientific Chief Engineer, discussed historical uses of ore and how to mitigate the effects thereof. The institute started research on uses of ore in 1970 because there were no regulations to prevent its use by private individuals. In 1986, Ukraine was the first in the Union of Soviet Socialist Republics to develop standards for use of the rock. The standards apparently are variable depending on what amounts of ${ }^{226} \mathrm{Ra},{ }^{230} \mathrm{Th}$, and ${ }^{40} \mathrm{~K}$ are contained in the ore. The consequences of using the ore were studied. Ore was used during construction in only a small number of houses and then generally only in the foundations. There was some use of ore in roads and sidewalks. The institute developed procedures to remove the material from the city. They are now developing a program to regulate usage. The highest measured concentration was $800 \mathrm{~Bq} / \mathrm{m}^{3}$ using the "eev or radon equivalent method" according to Mr. Molchanov. The reading of $800 \mathrm{~Bq} / \mathrm{m}^{3}$ is equivalent to $21.6 \mathrm{pCi} / \mathrm{L}$.

In a general discussion which followed, Mr. Masliakov outlined a number of problems that the Institute is having. They are experiencing the same difficulties as the rest of the country and need technological assistance from developed countries; they have no hard currency (and precious little government funding) with which to buy equipment in sufficient quantities; it is no longer prestigious to be a scientist because everyone wants to go into business; and they have poor information flow from the west.

\section{2:30 Lunch}

\section{2:00 Tour of the City Water Reservoir}

\section{3:30 Meeting with Director General}

Mr. Michael I. Babak is the Director General of the State Committee on Nuclear Power Use, Eastern Mining and Concentrating Complex. He controls the entire Zheltye Vody infrastructure. He and five of his subordinates met with the visitors in his office. 
Attending were: Mrs. Bogdan (SCNRS), Mr. Bereshnoi (SCNRS), Mr. Petrov, Mr. Bezrodniy, Mr. Maslikov, Mr. Zhukov, Mr. Tokar (NRC), and the author.

Mrs. Bogdan gave a brief introductory statement saying that the American guests of SCNRS were in Ukraine to provide some technical assistance in formulating a regulatory framework in which the Ukrainian mining and milling industry can exist.

$\mathrm{Mr}$. Tokar began by describing the function of the NRC, its history, and organization, also mentioning the U.S. Department of Energy, the national laboratories, the U.S. Environmental Protection Agency, OSHA, etc. His point was that industry in the USA must often satisfy all of these entities.

There were several questions about how American mills operated, which we tried to answer as best we could. It was clear from our visit that the Ukrainian mill is bigger than most American mills and that the Ukrainian method of handling mill tailings is far different from American methods. We expressed our concerns about their approach, as well as offering some recommendations. We felt that they should increase the amount of groundwater modeling that they conduct. We were also concerned, as were they, about the ease with which the public can gain access to the mill tailings ponds. We described the differences between the NRC philosophy of isolation (keep water away, prevent pooling and a bathtub effect) and the Ukrainian method (create large ponds in which the tailings exist).

The meeting was generally cordial, but several times it disintegrated into a general discussion between the potential licensee, SPA, and the potential regulator, SCNRS. At those times, our translator, Boris Landa, was unable to provide an accurate translation.

\section{7:00 Dinner with the Director General}

Mr. Babak and his staff joined the visitors at their hotel for a formal dinner that evening. As is typical, the evening consisted of many toasts to the health of the Ukrainian and American people and exchanges of pleasantries. 
October 6, 1994

We were driven back to Kiev via a slightly different route, traveling for approximately 8 hours. At one point during the trip, we stopped to visit a farmer's market. Boris Landa bought a large bunch of fresh raspberries wrapped in newsprint, which we all shared. 


\title{
INTERNAL DISTRIBUTION
}

\author{
1. B. A. Berven \\ 13. C. E. Pugh \\ 2. J. J. Blass \\ 14. R. S. Rohwer \\ 3. M. L. Espegren \\ 15. Central Research Library \\ 4. F. G. Gardner \\ 16 - 17. Laboratory Records \\ 5. D. K. Halford \\ 18. Laboratory Records - RC \\ 6. N. E. Korte \\ 19. ORNL Patent Section \\ 7. B. J. Krall \\ 20. ORNL Technical Library, Y-12 \\ 8-12. C. A. Little
}

\section{EXTERNAL DISTRIBUTION}

21. A.L. Eiss, U.S. NRC, Mail Stop T-8-A-23, Washington, D.C. 20555-001.

22. D. Titinsky, U.S. NRC, Mail Stop T-8-A-23, Washington, D.C. 20555-001.

23. M. Tokar, U.S. NRC, Mail Stop T-8-A-23, Washington, D.C. 20555-001.

24. Office of Assistant Manager, Energy Research and Development, Oak Ridge Operations Office, P.O. Box 2001, Oak Ridge, TN 37831-8600

25 - 26. Office of Scientific and Technical Information, U.S. Department of Energy, P.O. Box 62, Oak Ridge, TN 37831 